\title{
PERLINDUNGAN HUKUM BAGI PEMOHON KREDIT DENGAN MENGACU PADA ASAS KESEIMBANGAN ANTARA PELAKU USAHA (BANK) DAN KONSUMENNYA (PEMOHON KREDIT)
}

oleh:

\author{
Ni Luh Putu Sri Suryaningsih \\ (Konsentrasi Hukum Bisnis FH-Unud)
}

\begin{abstract}
Banking institutions as one of the financial institutions have a strategic role in supporting the economic life of a country. Banking institutions meant here as an intermediary of the parties who have surplus funds to the lack of funds. Banking activities that provide services on the economic sector that do not in spite of the risks that could harm the banks themselves and the customer. Relationship between the bank and the customer is bound to a credit agreement unnoticed by the debtor of his rights is often overlooked by the bank. Guaranteeing the law protection and law certainty for the debtors losing for such unilateral, the regulations of consumer protection, therefore, have important functions. The type of research used in this paper is the normative legal research. This research moved from the inclusion of the standard clause that would open up opportunities for businesses, especially banks to position the client, in this case the credit applicant, to be weaker than the bank.
\end{abstract}

Key words : bank (bank), perlindungan konsumen (consumer protection)

\section{PENDAHULUAN}

\subsection{Latar Belakang}

Perlindungan konsumen (consumer protection) merupakan salah satu sisi dari hubungan antara bidang perekonomian dengan bidang hukum yang memiliki peranan penting untuk dapat menjamin terciptanya kondisi perekonomian yang 
stabil. Dalam hal ini meliputi kegiatan ekonomi atau bisnis para pelaku usaha dengan para konsumen sebagai pihak pengguna barang maupun jasa yang diproduksi oleh para pelaku usaha. Bagi pelaku usaha, prinsip "dengan biaya yang sekecil-kecilnya untuk mendapatkan keuntungan yang sebesar-besarnya" sangat diperhatikan untuk mewujudkan suatu efektifitas dan efisiensi waktu maupun biaya salah satu terobosan yang dilakukan dalam pelayanannya terhadap konsumen yaitu dengan cara membuat klausula baku atau kontrak baku.

Demikian juga dalam dunia perbankan, terhadap transaksi pemberian kredit bagi para nasabahnya pihak perbankan memberlakukan perjanjian baku guna menghasilkan pelayanan yang cepat dan efisien. Dalam prakteknya, terdapat beberapa istilah yang sering dipergunakan untuk kontrak baku antara lain dalam bahasa Inggris disebut Standard Contract, Pad Contract dan dalam bahasa Belanda disebut Standaardregeling. ${ }^{1}$

Perjanjian Baku adalah perjanjian berbentuk tertulis yang telah digandakan berupa formulir-formulir, yang isinya telah distandarisasi atau dibakukan terlebih dahulu secara sepihak oleh pihak yang menawarkan (dalam hal ini pelaku usaha), serta ditawarkan secara masal,tanpa mempertimbangkan perbedaan kondisi yang dimiliki konsumen. Keseluruhan isi perjanjian baku berupa pasal-pasal dinamakan klausula baku (standardized clause). ${ }^{2}$

Dapat dikatakan bahwa kontrak baku adalah suatu kontrak tertulis yang dibuat hanya oleh salah satu pihak dalam kontrak tersebut, bahkan seringkali kontrak tersebut sudah tercetak (boilerplate) dalam bentuk formulir-formulir tertentu oleh salah satu pihak, yang dalam hal ini ketika kontrak tersebut ditandatangani umumnya para pihak hanya mengisikan data-data informatif tertentu saja dengan sedikit atau tanpa perubahan dalam klausula-klausulanya, dimana pihak lain dalam kontrak tersebut tidak mempunyai kesempatan atau hanya sedikit kesempatan untuk menegosiasi atau mengubah klausula-klausula

\footnotetext{
${ }^{1}$ Munir Fuady, 2003, Hukum Kontrak (Dari Sudut Pandang Hukum Bisnis), Citra Aditya Bakti, Bandung, hal.75.

${ }^{2}$ Ida Susanti \& Bayu Seto (editor), 2003, Aspek Hukum Dari Perdagangan Bebas: Menelaah Kesiapan Hukum Indonesia Dalam Melaksanakan Perdagangan Bebas, Citra Aditya Bakti, Bandung, hal.118.
} 
yang sudah dibuat oleh salah satu pihak tersebut sehingga biasanya kontrak baku sangat berat sebelah.

Hood Philips sebagaimana telah dikutip oleh Syahmin AK, menyatakan sebagai berikut:

"These contract (standard contract) are of the take it or leave it kind, for here the costumer cannot bargain over the terms: his only choice is to accept the terms in toto or to reject the service altogether". 3

Sehingga dari beberapa pengertian tersebut di atas, karakter dari perjanjian baku yakni telah ditetapkan secara tertulis mengenai isi kontrak dalam bentuk formulir yang digandakan dengan maksud untuk melayani permintaan para konsumen yang berfrekuensi tinggi. Dalam hal ini konsumen dalam banyak hal menduduki posisi tawar menawar (kedudukan transaksional) yang lebih rendah daripada produsen.

Dari karakter perjanjian baku tersebut, secara jelas menggambarkan posisi pelaku usaha yang menentukan secara sepihak klausula-klausula perjanjian pada posisi yang kuat sehingga konsumen berada pada posisi tawar yang tidak setara. Adanya bargaining position konsumen pada prakteknya jauh di bawah para pelaku usaha, maka Undang-undang tentang perlindungan konsumen merasakan perlu adanya pengaturan mengenai ketentuan perjanjian baku dan/atau pencantuman klausula baku dalam setiap dokumen atau perjanjian yang dibuat oleh pelaku usaha.

Bank dalam prakteknya biasanya telah menyediakan blanko atau formulir yang isinya telah dipersiapkan terlebih dahulu untuk setiap pemohon kredit. Namun dalam hal ini nasabah bank tidak turut serta dalam merumuskan terlebih dahulu mengenai isi perjanjian tersebut. Nasabah hanya dimintakan pendapatnya apakah dapat menerima syarat-syarat yang tersebut dalam formulir itu atau tidak. Artinya disini dapat berlaku prinsip take it or leave it, yang dalam hal ini tidak

\footnotetext{
${ }^{3}$ Syahmin AK, 2006, Hukum Kontrak Internasional, Raja Grafindo Persada, Jakarta, hal.141.
} 
adanya pilihan bagi pihak-pihak konsumen untuk secara bebas menentukan pilihannya.

Faktor yang menyebabkan bank menggunakan perjanjian baku dalam kegiatan usahanya yakni faktor efisiensi dan efektivitas. Faktor ini menjadi sangat penting karena bank berhadapan dengan nasabah yang jumlahnya banyak sehingga untuk memudahkan pelayanan dan mempersingkat waktu digunakan kontrak baku mengingat transaksi perbankan umumnya sejenis dan selalu terjadi secara berulang-ulang. Selanjutnya faktor untuk mengurangi tanggung jawab dari segala resiko yang mungkin timbul yaitu dengan menggunakan klausula eksonerasi, yaitu faktor keamanan. Pihak bank akan berusaha semaksimal mungkin agar dana yang dikelolanya benar-benar aman terhindar dari segala resiko sekecil apapun. ${ }^{4}$

Melihat dari kondisi tersebut, maka penting untuk diteliti selanjutnya dilakukan pengkajian terhadap perlindungan hukum bagi pemohon kredit dengan mengacu pada asas keseimbangan antara pelaku usaha (bank) dan konsumennya (pemohon kredit).

\subsection{Rumusan Masalah}

Berdasarkan latar belakang tersebut di atas, permasalahan yang dapat dirumuskan adalah sebagai berikut:

1) Apakah perjanjian kredit bank bertentangan dengan larangan penggunaan klausula baku dalam pasal 18 Undang-undang Nomor 8 Tahun 1999 tentang Perlindungan Konsumen?

2) Bagaimana pertanggungjawaban pihak bank terhadap perjanjian kredit yang mengandung klausula baku yang bertentangan dengan pasal $18 \mathrm{UU}$ Perlindungan Konsumen tersebut?

${ }^{4}$ Intan Sahat Sitompul, 2003, Eksistensi Klausula Eksonerasi Dalam Kontrak Baku di Dunia Perbankan dan Implikasinya Bagi Nasabah (Studi Kasus Permata Bank Medan), Tesis Program Pascasarjana Universitas Sumatra Utara Medan. 


\subsection{Tujuan Penelitian}

Dalam studi ilmu hukum dikenal adanya paradigma science as a process (ilmu sebagai proses). Adapun dari penelitian ini untuk mengetahui adanya perlindungan hukum bagi pemohon kredit yang mengacu pada asas keseimbangan antara pelaku usaha (bank) dan konsumennya (pemohon kredit).

\section{METODE PENELITIAN}

Metode penelitian dapat digunakan sebagai landasan dalam langkahlangkah menyusun suatu karya tulis. Metode menyangkut cara kerja untuk dapat memahami obyek yang menjadi sasaran ilmu yang bersangkutan yang merupakan jalan atau cara untuk memikirkan dan memeriksa sesuatu menurut rencana tertentu, ${ }^{5}$ Sedangkan penelitian yang dilakukan secara metodologis dan sistematis adalah suatu kegiatan ilmiah yang berkaitan dengan analisis dan konstruksi. ${ }^{6}$ Adapun jenis penelitian yang digunakan dalam penulisan ini adalah penelitian hukum normatif. Penelitian ini beranjak dari pencantuman klausula baku yang akan membuka peluang bagi pelaku usaha, khususnya pihak perbankan untuk memposisikan nasabah, dalam hal ini pemohon kredit, menjadi lebih lemah dibanding pihak bank. Oleh karena itu, perlu kiranya dikaji mengenai ada tidaknya pelanggaran atas pasal 18 Undang-undang Nomor 8 Tahun 1999 tentang Perlindungan Konsumen serta perlindungan hukum bagi pemohon kredit dengan mengacu pada adanya asas keseimbangan antara pelaku usaha (bank) dan konsumennya (pemohon kredit).

\section{HASIL DAN PEMBAHASAN}

\subsection{Perjanjian Kredit Bank ditinjau dari Undang-undang Nomor 8 Tahun 1999 Tentang Perlindungan Konsumen}

${ }^{5}$ M. Marwan \& Jimmy P., 2009, Kamus Hukum “Dictionary of Law Complete Edition”, Reality Publisher, Surabaya, hlm. 434.

${ }^{6}$ Soerjono Soekanto, 1986, "Pengantar Penelitian Hukum", Cetakan Ketiga, UI Press, Jakarta, hlm. 42. 
Perjanjian kredit bank sebagaimana telah diuraikan pada latar belakang diatas, cenderung menempatkan posisi tawar pemohon kredit menjadi lebih lemah sebagai akibat adanya klausula yang ditentukan secara sepihak oleh pihak perbankan. Meskipun pihak pemohon kredit telah menerima syarat-syarat dalam perjanjian yang berarti telah secara sukarela bersedia mengikatkan diri untuk menerima persyaratan-persyaratan yang dimaksud, penting kiranya adanya itikad baik dari pihak bank untuk menjaga agar terms and condition pada perjanjian tersebut memenuhi unsur-unsur keadilan, kepatutan, keseimbangan dan perlindungan bagi pihak yang secara faktual berada dalam posisi yang tidak seimbang.

Bila ditinjau dari hukum perjanjian, memang tidak ada pengaturan secara rinci mengenai batasan klausula baku dalam KUH Perdata yang diterapkan dalam praktek dunia usaha, sehingga hal ini menggambarkan belum diberikannya perlindungan yang seimbang bagi para pihak. Dengan diundangkannya Undangundang Nomor 8 Tahun 1999 tentang Perlindungan Konsumen (UUPK), kekosongan hukum tersebut menjadi terjawab melalui pengaturan dan batasanbatasan tentang bagaimana seharusnya perlindungan konsumen diberikan secara berimbang, berdasarkan keadilan dan kepastian hukum terhadap penggunaan perjanjian baku.

UUPK dalam hal ini telah menuangkan secara tegas dalam pasal 2 mengenai asas perlindungan konsumen yang digunakan sebagai landasan untuk mewujudkan perlindungan bagi konsumen, termasuk dalam penerapan perjanjian baku. Adapun beberapa asas perlindungan konsumen yang dimaksud disini yaitu Asas Manfaat, Asas Keadilan, Asas Keseimbangan, Asas Keamanan dan Keselamatan Konsumen, serta Asas Kepastian Hukum.

Adanya Asas Manfaat dimaksudkan agar segala upaya dalam penyelenggaraan perlindungan konsumen harus memberikan manfaat sebesarbesarnya bagi kepentingan konsumen dan pelaku usaha secara keseluruhan. Sehingga partisipasi seluruh rakyat dapat diwujudkan secara maksimal dan 
membedakan kesempatan kepada konsumen dan pelaku usaha untuk memperoleh haknya dan melaksanakan kewajibannya secara adil sesuai dengan Asas Keadilan.

Selanjutnya Asas Keseimbangan bertujuan untuk memberikan keseimbangan antara kepentingan konsumen, pelaku usaha, dan pemerintah. Begitu pula dengan Asas Keamanan dan Keselamatan Konsumen, yang dimaksudkan untuk memberikan jaminan atas keamanan dan keselamatan kepada konsumen dalam penggunaan, pemakaian, dan pemanfaatan barang dan jasa yang digunakan. Agar pelaku usaha maupun konsumen mentaati hukum dan memperoleh keadilan dalam penyelenggaraan perlindungan konsumen, serta Negara memberikan jaminan adanya kepastian hukum sesuai dengan Asas Kepastian Hukum.

Tentunya dalam perjanjian pemberian kredit antara pemohon dan pihak bank apabila ditinjau dari UUPK haruslah berpegang pada kelima asas di atas. Dari segi manfaat, perjanjian pemberian kredit pastinya telah memberikan manfaat yang besar bagi pemohon kredit yang membutuhkan bantuan financial, sehingga kebutuhan akan uang dapat terpenuhi melalui peran pelaku usaha yaitu perbankan. Demikian pula dari sisi pihak bank sendiri, dengan adanya transaksi pemberian kredit dapat meningkatkan keuntungan melalui rentang positif suku bunga bank atau positive spread (bunga pinjaman lebih tinggi daripada bunga simpanan). ${ }^{7}$

Yang juga perlu diperhatikan dalam perjanjian pemberian kredit adalah dari segi keseimbangan para pihak. Tentunya dengan penetapan sejumlah persyaratan oleh pihak bank dimaksudkan untuk menyeimbangkan pengeluaran dan resiko atas fasilitas pemberian kredit tersebut, namun upaya untuk menjaga kedudukan yang berimbang antara pelaku usaha dan konsumen haruslah tetap dijaga. Seringkali karena kurangnya informasi bagi pemohon kredit dan posisinya yang sangat tergantung pada bank pada akhirnya membuat nasabah harus tunduk pada perjanjian yang telah ditandatangani tersebut.

\footnotetext{
7 Ketut Rindjin, 2000, Pengantar Perbankan dan Lembaga Keuangan Bukan Bank, Gramedia Pustaka Utama, Jakarta, hal.112.
} 
Berdasarkan Pasal 1 angka 10 UUPK disebutkan bahwa:

"Klausula baku adalah setiap aturan atau ketentuan dan syarat-syarat yang telah dipersiapkan dan ditetapkan terlebih dahulu secara sepihak oleh pelaku usaha yang dituangkan dalam suatu dokumen dan/atau perjanjian yang mengikat dan wajib dipenuhi oleh konsumen."

Dengan adanya ketentuan ini, setiap syarat yang digunakan dalam dokumen (bon pembelian, kwitansi pembayaran, tanda penyerahan kiriman, dan lain sebagainya) atau perjanjian (perjanjian kredit bank, perjanjian pembelian, perjanjian asuransi, dan sejenisnya) dilarang dipergunakan sepanjang bertentangan dengan ketentuan sebagaimana telah tertuang dalam pasal 18 UUPK yang menetapkan bahwa dalam menawarkan barang dan/atau jasa yang ditujukan untuk diperdagangkan dilarang membuat atau mencantumkan klausula baku pada setiap dokumen dan/atau perjanjian apabila klausula baku tersebut: ${ }^{8}$

(1) Isinya:

a. Menyatakan pengalihan tanggung jawab pelaku usaha;

b. Menyatakan bahwa pelaku usaha berhak menolak menyerahkan kembali barang yang dibeli konsumen;

c. Menyatakan bahwa pelaku usaha berhak menolak penyerahan kembali uang yang dibayarkan atas barang dan/atau jasa yang dibeli oleh konsumen;

d. Menyatakan pemberian kuasa dari konsumen kepada pelaku usaha baik secara langsung maupun tidak langsung untuk melakukan segala tindakan sepihak yang berkaitan dengan barang yang dibeli oleh konsumen secara angsuran;

e. Mengatur perihal pembuktian atas hilangnya kegunaan barang atau pemanfaatan jasa yang dibeli oleh konsumen;

${ }^{8}$ Ida Susanti \& Bayu Seto (editor), Op.cit., hal.120. 
f. Memberi hak kepada pelaku usaha untuk mengurangi manfaat jasa atau mengurangi harta kekayaan konsumen yang menjadi objek jual beli jasa;

g. Menyatakan tunduknya kepada peraturan yang berupa aturan baru, tambahan, lanjutan dan/atau pengubahan lanjutan yang dibuat sepihak oleh pelaku usaha dalam masa konsumen memanfaatkan jasa yang dibelinya;

h. Menyatakan bahwa konsumen memberi kuasa kepada pelaku usaha untuk pembebanan hak tanggungan, hak gadai, atau hak jaminan terhadap barang yang dibeli oleh konsumen secara angsuran.

(2) Letak atau bentuknya:

a. sulit terlihat;

b. tidak dapat dibaca secara jelas.

(3) Pengungkapannya sulit dimengerti.

Dalam perjanjian pemberian kredit bank terdapat beberapa klausula baku yang dianggap merugikan kedudukan salah satu pihak yang secara ekonomi lebih lemah dari pihak yang lain yaitu nasabah, diantaranya tentang jaminan dan jaminan tambahan serta cara pengikatannya, pelaksanaan eksekusi barang jaminan, pelunasan kembali sebelum jangka waktu pelunasan dan kuasa yang tidak dapat ditarik kembali.

Mengenai jaminan dan cara pengikatannya, terdapat klausula yang menyatakan bahwa debitur menyetujui dan mewajibkan serta mengikatkan diri untuk memberikan bantuan guna memungkinkan bank melaksanakan pengikatan barang jaminan kredit menurut cara dan pada saat yang dianggap baik oleh bank dan memberikan kuasa kepada bank yaitu kuasa yang tidak dapat ditarik kembali sebelum utangnya kepada bank dilunasi, yang merupakan kuasa mutlak untuk menjual barang jaminan yang dijaminkan maupun jaminan tambahan. 
Apabila dalam pelaksanaan eksekusi nilai jaminan pokok tidak cukup untuk membayar seluruh utang dan bunga bank,maka debitur menyetujui dan mewajibkan serta mengikatkan diri untuk dan atas permintaan pertama dari bank membayar kepada bank sejumlah uang menurut ketetapan bank atau menambah barang-barang atau benda-benda tertentu oleh bank untuk dijadikan jaminan tambahan menurut ketetapan bank.

Dalam melaksanakan bisnis perbankan, ada prinsip kehati-hatian yang harus diterapkan oleh bank terutama dalam hal penilaian benda jaminan yang diberikan oleh debitur. Tentunya pihak bank dalam melakukan penilaian benda jaminan telah menilai cukup bahwa nilai benda jaminan mampu menutupi seluruh nilai utang berikut bunganya apabila debitur wanprestasi. Akan tetapi bank masih mencantumkan klausula bagi debitur untuk memberi tambahan benda jaminan bilamana nilai jaminan awal tidak mencukupi pada saat eksekusi.

Klausula demikian tersebut jelas merugikan pihak debitur karena pada saat pelaksanaan eksekusi, debitur tidak pernah dilibatkan oleh pihak bank karena debitur sudah memberikan kuasa yang tidak dapat ditarik kembali kepada bank untuk melaksanakan eksekusi. Menurut ketentuan Undang-undang Nomor 4 Tahun 1996 tentang Hak Tanggungan, seharusnya benda jaminan tersebut dieksekusi melalui lelang. akan tetapi, yang sering terjadi apabila debitur wanprestasi adalah dilakukan eksekusi terhadap benda jaminan tanpa dilakukan lelang dan biasanya debitur tidak mengetahui siapa yang membeli benda jaminannya. Selain itu, seringkali dalam eksekusi tersebut benda jaminan dinilai jauh di bawah harga pasaran yang wajar yang akhirnya mengakibatkan pelunasan terhadap seluruh utang beserta bunga-bunganya menjadi kurang dan pihak bank meminta tambahan benda jaminan untuk melunasi seluruh sisa utang beserta bunganya.

Adanya klausula baku seperti yang disebut di atas, maka klausula-klausula ini mengesampingkan hak-hak konsumen yang tercantum dalam Pasal 4 huruf c 
UUPK yaitu "hak atas informasi yang benar, jelas, dan jujur mengenai kondisi dan jaminan barang dan/atau jasa".

\subsection{Pertanggungjawaban Pihak Bank Terhadap Perjanjian Kredit yang Mengandung Klausula Baku yang Bertentangan Dengan Pasal 18 UUPK}

Dalam konteks hukum perlindungan konsumen, sebagaimana tertuang dalam ketentuan UUPK maka terdapat beberapa jenis pertanggungjawaban hukum, yaitu Pertanggungjawaban Kontraktual (Contractual Liability), Pertanggungjawaban Produk (Product Liability), Pertanggungjawaban Profesional (Professional Liability), dan dalam hal tertentu menggunakan Pertanggungjawaban Langsung (Strict Liability). ${ }^{9}$ Apabila barang/jasa yang diproduksi dan/atau diperdagangkan menimbulkan kerugian bagi konsumen, maka pihak yang dibebankan untuk memberikan ganti kerugian kepada konsumen dalam semua jenis pertanggungjawaban hukum tersebut adalah pelaku usaha. Mengingat bank sebagai lembaga keuangan yang bergerak dibidang jasa, maka bentuk pertanggungjawaban dalam hukum perlindungan konsumen adalah melalui Pertanggungjawaban Profesional dan/atau Pertanggungjawaban Kontraktual.

\subsubsection{Pertanggungjawaban Kontraktual}

Klausula baku yang menimbulkan ketidakseimbangan pengaturan hak dan kewajiban antara pihak bank dengan debitur, secara yuridis telah diatur dalam Pasal 18 UUPK. Larangan pencantuman klausula baku yang mengandung klausula eksonerasi dimaksudkan untuk menempatkan kedudukan debitur setara dengan pihak bank berdasarkan prinsip kebebasan berkontrak.

Berdasarkan ketentuan yang tercantum dalam UUPK, pelaku usaha yang mencantumkan klausula baku dengan isi, letak, bentuk, atau pengungkapannya

${ }^{9}$ Agus Santoso dan Dyah Pratiwi, 2010, Tanggung Jawab Penyelenggara Sistem Elektronik Perbankan dalam Kegiatan Transaksi Elektronik Pasca UU No. 11 Tahun 2008, available from http://www.djpp.depkumham.go.id/hukum-teknologi/665-tanggung-jawabpenyelenggara-sistem-elektronik-perbankan-dalam-kegiatan-transaksi-elektronik-pasca-uu-no-11tahun-2008.html, diakses pada tanggal 16 September 2012. 
seperti diuraikan di atas dalam dokumen atau perjanjian baku yang dibuatnya dapat dikenakan sanksi sebagai berikut: ${ }^{10}$

a. Sanksi Perdata

- Klausula baku tersebut jika digugat di pengadilan oleh konsumen, akan menyebabkan hakim harus membuat putusan declaratoir bahwa klausula tersebut batal demi hukum (void) (Pasal 18 ayat (3) UUPK);

- Pelaku usaha yang pada saat ini mencantumkan klausula baku dalam dokumen atau perjanjian baku yang digunakannya, wajib merevisi klausula baku yang digunakannya itu agar sesuai dengan UUPK dengan batas waktu sampai tanggal 20 April 2000 (Pasal 18 ayat (4) UUPK).

b. Sanksi Pidana

Mengenakan sanksi pidana kepada pelaku usaha yang melanggar pasal 18 UUPK sebagaimana ditetapkan dalam pasal 62 ayat (1) UUPK yaitu dipidana dengan pidana penjara paling lama 5 (lima) tahun atau pidana denda paling banyak Rp.2.000.000.000,- (dua miliar rupiah).

\subsubsection{Pertanggungjawaban Profesional}

Ketentuan mengenai pertanggungjawaban professional telah diatur dalam Pasal 8 sampai dengan Pasal 17 UUPK. Dalam hal pelaksanaan pemberian kredit perbankan, perlindungan konsumen terkait pertanggungjawaban professional dapat kita temukan dalam pasal 10 UUPK yaitu:

"Pelaku usaha dalam menawarkan jasa yang ditujukan untuk diperdagangkan menawarkan, mempromosikan, mengiklankan atau membuat pernyataan yang tidak benar dan menyesatkan mengenai:

1. harga atau tarif suatu jasa;

2. kegunaan suatu jasa;

${ }^{10}$ Ida Susanti \& Bayu Seto (editor), Op.cit.,hal.122. 
3. kondisi, tanggungan, jaminan, hak atau ganti rugi suatu jasa;

4. tawaran potongan harga atau hadiah menarik yang ditawarkan;

5. bahaya penggunaan jasa.

Pelaku usaha yang di dalam memberikan jasanya melanggar ketentuan tersebut di atas, dan kemudian ternyata menimbulkan kerugian pada badan, jiwa, dan barang milik konsumen, maka pelaku usaha dapat dikenakan sanksi sebagai berikut:

a. Sanksi Perdata

Apabila pemberian jasa oleh professional menggunakan suatu perjanjian baku yang mencantumkan klausula baku yang berisi klausula eksonerasi, maka sanksi perdata yang dapat dikenakan adalah sanksi yang tercantum dalam Pasal 18 UUPK. Selain itu, apabila perjanjian pemberian jasa tersebut melanggar ketentuan yang tercantum dalam Pasal 8 sampai dengan Pasal 17 UUPK, maka berarti perjanjian pemberian jasa tersebut tidak memenuhi syarat sebab/kausa yang halal dalam Pasal 1320 KUHPerdata. Apabila hal ini dilanjutkan ke Pengadilan, hakim harus menetapkan putusan yang declaratoir bahwa perjanjian pemberian jasa tersebut batal demi hukum (void).

b. Sanksi Pidana

Sebagaimana ditetapkan dalam Pasal 62 ayat (1) dan (2) UUPK maka pelaku usaha yang melanggar ketentuan dia atas dipidana dengan pidana penjara paling lama 5 (lima) tahun/2 (dua) tahun, atau pidana denda paling banyak Rp. 2.000.000.000,- (Dua Milliar Rupiah)/Rp. 500.000.000,(Lima Ratus Juta rupiah) sesuai dengan pasal yang dilanggar.

\section{Simpulan dan Saran}

\subsection{Simpulan}


1) Bahwa dalam perjanjian pemberian kredit bank terdapat beberapa klausula baku yang bertentangan dengan ketentuan pasal 18 UUPK dan dianggap merugikan kedudukan salah satu pihak yang secara ekonomi lebih lemah dari pihak yang lain yaitu nasabah, di antaranya tentang jaminan dan jaminan tambahan serta cara pengikatannya, pelaksanaan eksekusi barang jaminan, pelunasan kembali sebelum jangka waktu pelunasan dan kuasa yang tidak dapat ditarik kembali.

2) Pertanggungjawaban Pihak Bank Terhadap Perjanjian Kredit yang Mengandung Klausula Baku yang Bertentangan Dengan Pasal 18 UUPK menimbulkan bentuk pertanggungjawaban secara kontraktual maupun secara professional. Secara kontraktual maupun profesional, terdapat sanksi perdata dalam hal klausula baku tersebut diajukan gugatan di pengadilan oleh nasabah, maka hakim harus membuat putusan declaratoir bahwa klausula tersebut batal demi hukum (void) (Pasal 18 ayat (3) UUPK); dan sanksi pidana dalam pertanggungjawaban kontraktual diatur dalam pasal 62 ayat (1) UUPK yaitu dipidana dengan pidana penjara paling lama 5 (lima) tahun atau pidana denda paling banyak Rp.2.000.000.000,- (dua miliar rupiah). Untuk sanksi pidana dalam pertanggungjawaban professional diatur dalam Pasal 62 ayat (1) dan (2) UUPK yakni pelaku usaha yang melanggar ketentuan diatas dipidana dengan pidana penjara paling lama 5 (lima) tahun/2 (dua) tahun, atau pidana denda paling banyak Rp. 2.000.000.000,- (Dua Milliar Rupiah)/Rp. 500.000.000,- (Lima Ratus Juta rupiah) sesuai dengan pasal yang dilanggar.

\subsection{Saran}

Selanjutnya, pihak bank di dalam menjalankan usahanya hendaknya harus memperhatikan etika bisnis, tidak dengan sengaja membuat klausula yang dapat merugikan kepentingan debitur dengan memanfaatkan posisi tawar debitur yang lemah, baik secara ekonomi maupun dari segi keterbatasan informasi. 


\section{DAFTAR PUSTAKA}

AK, Syahmin, 2006, Hukum Kontrak Internasional, Raja Grafindo Persada, Jakarta.

Fuady, Munir, 2003, Hukum Kontrak (Dari Sudut Pandang Hukum Bisnis), Citra Aditya Bakti, Bandung.

Marwan, M. \& Jimmy P., 2009, Kamus Hukum "Dictionary of Law Complete Edition”, Reality Publisher, Surabaya.

Rindjin, Ketut, 2000, Pengantar Perbankan dan Lembaga Keuangan Bukan Bank, Gramedia Pustaka Utama, Jakarta.

Santoso, Agus dan Dyah Pratiwi, 2010, Tanggung Jawab Penyelenggara Sistem Elektronik Perbankan dalam Kegiatan Transaksi Elektronik Pasca UU No. $11 \quad$ Tahun 2008, available from http://www.djpp.depkumham.go.id/hukum-teknologi/665-tanggungjawab-penyelenggara-sistem-elektronik-perbankan-dalam-kegiatantransaksi-elektronik-pasca-uu-no-11-tahun-2008.html, diakses pada tanggal 16 September 2012.

Sitompul, Intan Sahat, 2003, Eksistensi Klausula Eksonerasi Dalam Kontrak Baku di Dunia Perbankan dan Implikasinya Bagi Nasabah (Studi Kasus Permata Bank Medan), Tesis Program Pascasarjana Universitas Sumatra Utara Medan.

Soekanto, Soerjono, 1986, "Pengantar Penelitian Hukum", Cetakan Ketiga, UI Press, Jakarta.

Susanti, Ida \& Bayu Seto (editor), 2003, Aspek Hukum Dari Perdagangan Bebas: Menelaah Kesiapan Hukum Indonesia Dalam Melaksanakan Perdagangan Bebas, Citra Aditya Bakti, Bandung.

Undang-undang Nomor 8 Tahun 1999 tentang Perlindungan Konsumen

Undang-undang Nomor 4 Tahun 1996 tentang Hak Tanggungan 